\title{
PREDICTION OF MOISTURE CONTENT \\ OF GRAINS DURING RE-WETTING PROCESS FOR MILLING
}

\author{
Arafa $^{1}$, G. K. and A. A. Abd El-Rahmam ${ }^{2}$
}

\begin{abstract}
The main objectives of the present research work were to study the effects of moisture content on some characteristics of grains, the method could be used by grain industry to sequence be have moisture content during rewetting processing and to predict moisture content by calibration of electric resistance of grains to increase grain quality in order to minimize grain.Corn variety 10, Wheat variety Giza 168 and Rice variety Sakha 103 grains were used in the experiments as re-wetting process and measurements. Grains were with the initial moisture content of about $12.5 \%, 12 \%$ and $11 \%$ (b.d) for corn, wheat and rice grains. The grains were milled using hammer mill. The following most tmprtant results conclusions were found, 1) The suitable moisture content was 16, 15.5 and $16.5 \%$ of corn, wheat and rice grains, respectively at about $1.5 \mathrm{~h}$ of re-wetting time. Which lead to increase weight of 1000 grains was 470, 43 and $26 \mathrm{~g}$, and water absorbed of grains were 0.0279, 0.0023 and $0.0017 \mathrm{~g}$. Meanwhile, the electric resistance of grains was decreased, which were 35.95, 35.1 and 32.2 Omme and terminal velocity was 70.5, 45.9 and $28.9 \mathrm{~m} / \mathrm{s}$, and hardness of grains was decreased, which was 189 , 37.5 and $24 N$ of corn, wheat and rice grains, respectively 2) By increasing the moisture content of corn, wheat and rice grains during rewetting process. The weight and water absorbed were increased. Meanwhile, the hardness and electric resistance were decreased. 3) The correlation factor between the moisture content and electric resistancewas 0.98, 0.97 and 0.97 for corn, wheat and paddy rice grains during re-wetting process, respectively. That is mean the correlation factorwas ranged between $r=0.97-0.98$ which is considered that the correlation relationship between the moisture content and electric resistance more significant and high.
\end{abstract}

1-Senior Researcher, Agric. Eng. Res. Institute, Agric.Res.Center, Dokki, Egypt. 2-Head of Researchers, Agric. Eng. Res. Institute, Agric.Res.Center, Dokki, Egypt. 
4) Re-wetting process before the grinding lead to reduction percentage of consumption energy about $20 \%$ of grains and 5) re-wetting of grains can be important for the milling process and softens the endosperm to increase flour extraction and reduces the power consumption during the milling process.

\section{INTRODUCTION}

There are many variables to consider when re-wetting grain: grain hardness, protein content, the mill's ambient temperature, grain Lemperature, moisture content of the dry grain, and target moisture content of theconditioned grain. Dick and Matsuo (1988). reported that several common factors such as moisture content, granulation, color, speck count, ash content, protein content and amylase activity are often considered when judging semolina quality. Bizzarri and Morelli (1988) reported that for amber durum wheat, 16-24 h of rewetting at $17-17.5 \%$ moisture and for white durum wheat, $12-16 \mathrm{~h}$ at $16-$ $16.5 \%$ moisture provide typical conditions for milling. In reality, no valid study demonstrates that all varieties of durum wheat with small kernels. The 1000-kernel weight is a measure of average kernel size. A greater milling yield is expected with larger kernels because the ratio of endosperm to bran should be greater (Matsuo, 1988). Hazen and Ward (1997) pointed out that wheat milling and baking quality is a function of the physical and chemical traits of grain and flour. Also, these properties were very important in the process of wheat milling. Laskowski and Lysiak (1997) mentioned that the energy consumption during grinding depends on the kinematic and geometric parameters of a grinding machine and physical properties of threw grinding material. From among the physical properties of kernel the greatest influence on power demand during the grinding process is exerted by mechanical properties, especially hardness of kernel. Therefore it is important to evaluate the influence of kernel mechanical properties on energy-consuming indexes of wheat grinding process. They are using three methods of image analysis were investigated: morphological opening, constant grey level run lengths and grey level spatial inter dependences to squired images of particle size of milling products ( Novales et al., 1998) 
Cnossen and Siebenmorgen (2000) mentioned that the fissures are cracks in the rice kernel, during milling, rice kernels with fissures tend to break, causing lower head and total percentages. Rice is subject to fissuring when it is below critical combinations of temperature and moisture, either in the field or after harvest. The cause of fissuring occurs when rice kernels are exposed to humidity near $100 \% \mathrm{RH}$ or water after they have dried below a critical moisture ranging between 14 to $18 \%$. The very hard durum grain must be tempered to relatively high moisture content (16.0-16.5\%) before grinding. This moisture content toughens the seed coat so that efficient separation of bran and endosperm can take place (Donnelly and Ponte, 2000). Grain Moisture content represents another aspect of quality for durum wheat milling. The percentages of other components, such as protein and starch and consequently kernel test weight are inversely related to moisture content. In addition, grain in excess of $13.5 \%$ moisture may heat during storage, with sprouting, fungal damage and deterioration in condition (Troccoli et al., 2000). Processes of heat and mass exchange that take place in the course of wheat grain wetting and drying, cause inner stress resulting in endosperm cracks. These cracks cause specific physical and biological effects, as reported by Woyniak, (2001). Mark (2003) mentioned that the wheat re-wetting process is important to most millers. To maximize the extraction of flour, millers mix water into the wheat as part of its preparation for the milling process. Re-wetting wheat to the optimal milling moisture softens the endosperm while toughening the bran. Softening the endosperm increases flour extraction and reduces the power consumption and noise level of the roller mills during the milling process. Thiex and Richardson (2003) proposed that the term "weight loss on drying" should be substituted for the term "moisture" when discussing feeds. Hence, the term "dry matter" probably should be replaced with "100 minus weight loss on drying." Wheat to roll moisture is a measurement of how well the wheat was prepared for milling and how well moisture is added. Moisture addition influences both product yield and mill operation (Owens, 2003). The endosperm, or heart of the wheat kernel, does not breakdown into fine powdery flour when milled, because the endosperm of durum is hard enough to hold together during milling, and the result is a granular product called semolina, which is used to make spaghetti and other pasta 
products (Connell et al., 2004). Hashemi et al. (2005) reported that the ICE has hygroscopic properties if it is moved from one environmental to another; the grain can lose or gain moisture from the surrounding environment. Farmers all over the world have increased the production of rice by adopting modern technology and efficient management techniques. However, quality and quantity losses still occur at the preand post-harvest phases, when many factors influence the ultimate quality of grains. Re-wetting time should be long enough to allow the moisture in the kernels to comet equilibrium and equally toughen the bran and mellow the endosperm of all sizes of kernels. Experienced millers know that having clean, consistent, well-prepared wheat at the first grinding stage is a key component toward mill balance, which results in the most favorable flour extraction and flour quality (Posner and Hibbs, 2005). Hashemi et al. (2009) noticed that if the final moisture content has varied in the paddy layers, subsequently it could break paddy during the milling process. To overcome this problem, normally millers have increased the drying time that the difference reduces to a minimum and it results in higher crack in kernels. This problem motivated us to investigate the approach of uniform final MC in different layers of paddy by using a discharge fan to transfer the humid heated air and assessing this method at different heights of paddy when the final moisture content reaches about 8\% (w.b.). Stoenescu et al. (2010) said that the Romanian wheat, Dropia variety, was cleaned and tempered in an industrial roller mill. Technological effects of the wheat cleaning equipment were investigated as function of the total impurities removed from the cereals. The impurities separated through combine-cleaner and indented separators were 83.42 and $82.83 \%$, respectively. Doblado-Maldonado et al. (2013) studied that to produce whole grain wheat flour on a laboratory-scale with particle size distributions similar to commercially-milled samples without re-milling the bran. The moisture contents of four hard winter wheat cultivars were adjusted to $7.29-7.98 \%$ (by drying), $9.00-10.6 \%$ ("as is"), and $15.6 \%$ (by tempering) prior to milling into wholegrain flour.

The main objectives are as follows:

1- To study the effect of moisture content on some characteristics of grains, 
2- The method could be used by grain industry to sequence behave moisture content during re-wetting processing and

3- To predict with moisture content by calibration of electric resistance of grains to increase grain quality.

\section{MATERIAL AND METHODS}

\section{Sample preparation}

Grains of corn, wheat and paddy rice were selected from the sample of Agr. Res.Center. Corn variety 10, Wheat variety Giza 168 and paddy rice variety Sakha 103 grains were used in the experiments as re-wetting process and measurements. Tests were performed for $5 \mathrm{~kg}$ of each grain varieties. Grains were with the initial moisture content of about 12.5, 12 and $11 \%$ (b.d) for corn, wheat and rice grains, respectively.Prior to milling the grainsis mainly cleaned of impurities by screening to remove different type of impurities.The experiments were carried out at Process and Handling of Agric. Production Lab in Agric. Eng. Res. Institute through season 2014.

Physical properties of grain, grain sizes were determined by measuring the length $(\mathrm{L})$, width $(\mathrm{W})$ and thickness $(\mathrm{T})$ for each grain in the sample by using the digital caliber. Some Physical and mechanical properties of grains were listed in Table (1).To measure some of the physical properties of grains, it was measured by El-Raie, (1987).

Table (1):Main dimensions and some physical and mechanical properties of corn, wheat and rice grains.

\begin{tabular}{|l|c|c|c|}
\hline Measurement & Corn & Wheat & Paddy Rice \\
\hline Length, mm & 12.37 & 6.15 & 6.68 \\
\hline Width, mm & 9.89 & 3.45 & 2.83 \\
\hline Thickness, mm & 4.36 & 2.7 & 2.02 \\
\hline Weight, g & 0.413 & 0.03 & 0.032 \\
\hline Bulk density, kg/m3 & 1495 & 1023 & 820 \\
\hline Terminal velocity, m/s. & 60 & 32 & 20 \\
\hline Hardness, N & 259 & 56 & 39 \\
\hline Moisture content, \% & 12.5 & 12 & 11 \\
\hline
\end{tabular}

INSTRUMENTS:

Moisture content meter of grain, has the following specifications: 1) The moisture tester model is SP - 1D, 2) Manufactured by Japan, 3) 
Accuracy is $\mp 0.5 \%, 4)$ The power source is $220 \mathrm{~V}$, and 5) The ambient working temperature from 0 to $40{ }^{\circ} \mathrm{C}$.

Digital balance, source of manufacture: Germany; Model: SBA 51; and Accuracy $0.01 \mathrm{~g}$. It was used to determine the weight of individual grains.

Digital venire caliper, it has an accuracy of $0.01 \mathrm{~mm}$. It was used to measure the dimensions of individual grains.

Grain hardness test, hardness of the wheat kernels was tested using hardness tester (model 174886 kiyaseisakusho LTD). The hardness value of each sample was recorded for kilogram and calculated for Newton.

\section{Re-wetting process:}

Re-wetting process conditioned a process where by moisture is added or subtracted as necessary to ensure uniformity in the grain, and to prepare it for the separation of the endosperm from the bran layers. Method of rewetting was depended on add water to wheat grain for $18 \mathrm{~h}$, according to the following equation, (Abd EL-Kader, (1995)):

$$
\begin{aligned}
& D_{1} W_{1}=D_{2} W_{2} \\
& X=W_{2}-W_{1}
\end{aligned}
$$

Where: $\mathrm{D}_{1}=100-\mathrm{M}_{1}\left(\mathrm{M}_{1}\right.$ : Moisture content before tempering, w.b\%);

$\mathrm{D}_{2}=100-\mathrm{M}_{2}\left(\mathrm{M}_{2}\right.$ : Moisture content after tempering, wb\%);

$\mathrm{W}_{1}=$ weight of grains before tempering, $\mathrm{g}$;

$\mathrm{W}_{2}=$ weight of grains after tempering, $\mathrm{g}$; and

$\mathrm{X}=$ weight of absorbed water, $\mathrm{g}$.

Grinder (miller) grains, milling process is considered very important to high quality and increase use efficiency of grains crops. The grain should produce a high yield of flour with maximum and clean separation from the bran and germ without excessive consumption of power. Specifications of miller were followed, Manufacture, Germany;Miller speed, $2840 \mathrm{rpm}$; Power, 1100 watt and Blats No., 3.

\section{RESULTS AND DISCUSSION}

Cereal grains are damaged by the operation of agricultural machinery during harvest and transportation. Also, they are damaged during postharvest processing. Fig. 1 shows the effect of soaking time on moisture content, electric resistance, weight and water absorbed of grains during re-wetting process before starting the industrial of grains milling for wheat and corn grains and husking for paddy rice. 


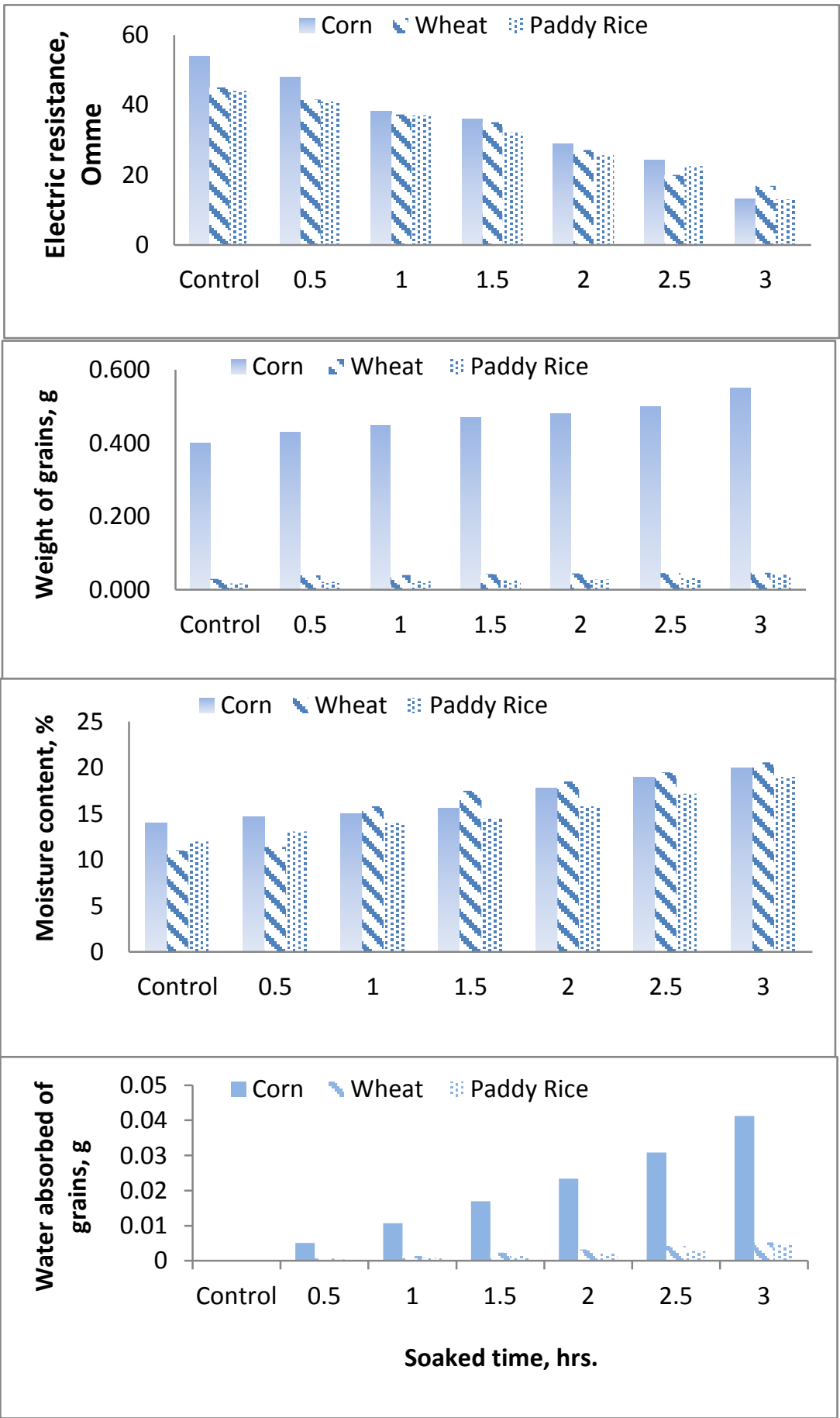

Fig. 1 : Effect soaking time on moisture content, electric resistance, weight and water absorbed of grains. 
For re-wetting process during three hours, it was noticed that the moisture content increased from (12.4 to $20 \%),(12$ to $20 \%)$ and (11 to $20 \%)$ for corn, wheat and paddy rice grains crops respectively. At increased soaking time from 0.5 to $3 \mathrm{~h}$ during re-wetting process, respectively. The weight of grains was increased from( 0.40 to $0.55 \mathrm{~g}),(0.03$ to $0.047 \mathrm{~g}$ ) and $(0.018$ to $0.042 \mathrm{~g}$ ) for corn, wheat and paddy rice grains crops respectively. At increased soaking time from 0.5 to $3 \mathrm{~h}$ during re-wetting process, respectively. The water absorbed of grains was increased from $(0.0000$ to $0.0618 \mathrm{~g}),(0.0000$ to $0.0053 \mathrm{~g})$ and $(0.0000$ to $0.0050 \mathrm{~g})$ for corn, wheat and paddy rice grains crops respectively. At increased soaking time from 0.5 to $3 \mathrm{~h}$ during re-wetting process, respectively. While, the electric resistance of grains was decreased from (54 to 13.2 Omme),(45 to 16.9 Omme) and (44 to 13 Omme) for corn, wheat and paddy rice grains crops respectively At increased soaking time from 0.5 to $3 \mathrm{~h}$ during re-wetting process, respectively. According to the previous results, the suitable moisture content was $16,15.5$ and $16.5 \%$ of corn, wheat and rice grains, respectively. Which lead to increase weight of grains were $0.47,0.043$ and $0.026 \mathrm{~g}$ and water absorbed of grains were $0.0279,0.0023$ and $0.0017 \mathrm{~g}$., while the electric resistance of grains was decreased, which were $35.95,35.1$ and $32.20 \mathrm{mme}$ of corn, wheat and paddy rice grains, respectively at about $1.5 \mathrm{hrs}$ of re-wetting time.

Fig. 2 shows the effect of soaking time on terminal velocity, hardness and weight 1000 grains of grains during re-wetting process. For re-wetting process during three hours, it was noticed that the terminal velocity increased from (60 to $82.5 \mathrm{~m} / \mathrm{s}),(32$ to $50 \mathrm{~m} / \mathrm{s}$ ) and $(20$ to $50 \mathrm{~m} / \mathrm{s})$ for corn, what and paddy rice grains crops respectively At increased soaking time from 0.5 to $3 \mathrm{~h}$ during re-wetting process, respectively. The weight of 1000 grains was increased from (400 to $550 \mathrm{~g}$ ), (35 to $47 \mathrm{~g}$ ) and (18 to $45 \mathrm{~g})$ for corn, wheat and paddy rice grains crops respectively At increased soaking time from 0.5 to $3 \mathrm{~h}$ during re-wetting process, respectively. Meanwhile, the hardness of grains was decreased from (259 to $155 \mathrm{~N}),(56$ to $21.45 \mathrm{~N})$ and (39 to $17 \mathrm{~N})$ for corn, wheat and paddy rice grains crops Respectively At increased soaking time from 0.5 to $3 \mathrm{~h}$ during re-wetting process, respectively. According to the previous results, the suitable terminal velocity was $70.5,45.9$ and $28.9 \mathrm{~m} / \mathrm{s}$ of corn, wheat 
and paddy rice gain grains, respectively. Which lead to increase weight of 1000 grains was 470,43 and $26 \mathrm{~g}$, while the hardness of grains was decreased, which was $189,37.5$ and $24 \mathrm{~N}$ of corn, wheat and paddy rice grains, respectively at about $1.5 \mathrm{~h}$ of re-wetting time.

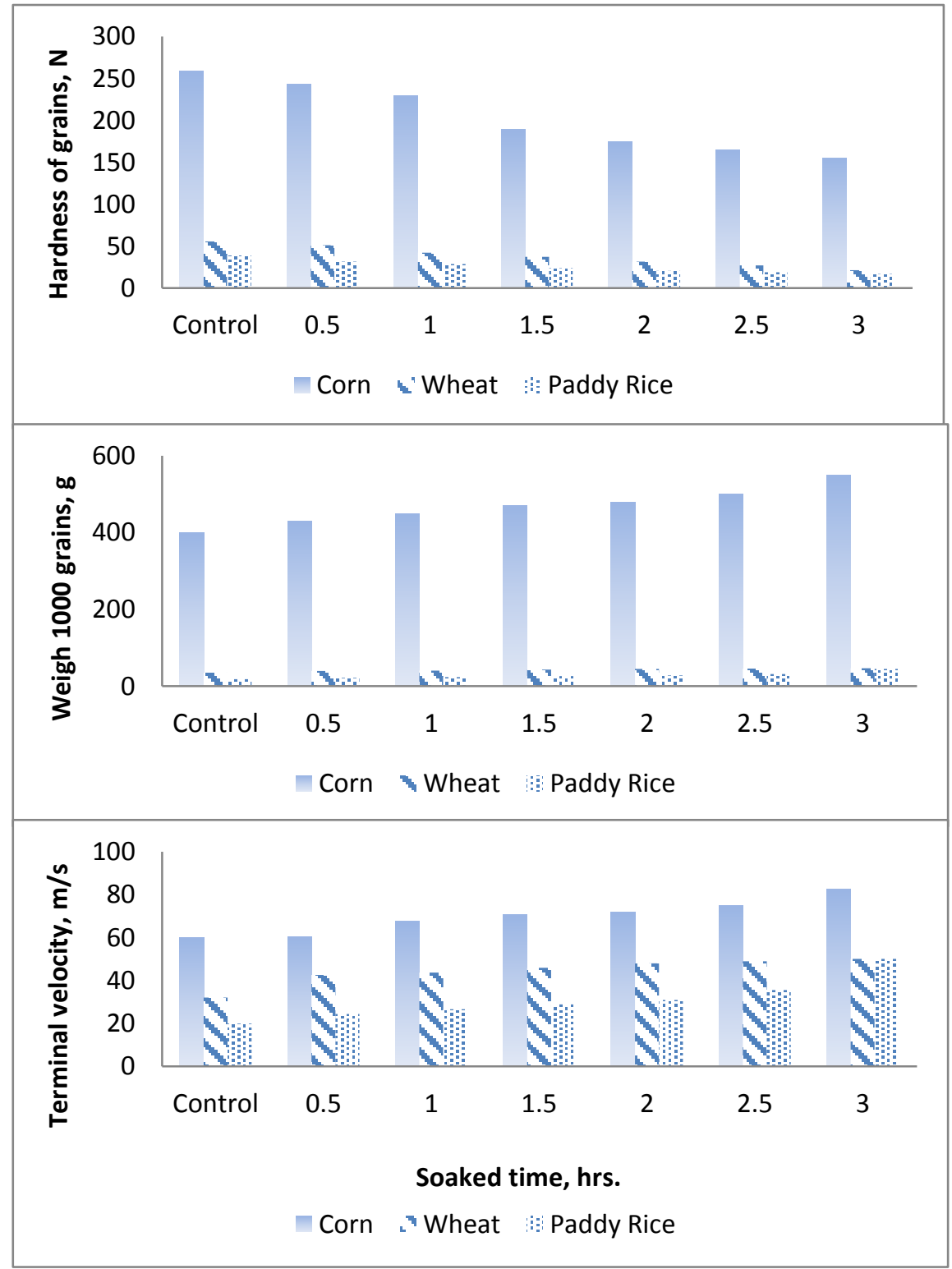

Fig. 2 : Effect soaking time on hardness, weight of 1000 and terminal velocity 
Fig. 3 shows the effect of moisture content on weight and water absorbed of grains during re-wetting process before starting the industrial of grains milling for wheat and corn grains and husking for paddy rice. It was noticed that the moisture content increased, which ranged from 12.5 to 20 $\%$ for corn, from 12 to $20 \%$ for wheat and from 11 to $20 \%$ for paddy rice grains during re-wetting process, respectively. The increasing of moisture content was lead to increase in weight of grains (from 0.4 to $0.55 \mathrm{~g}$ ), (from 0.03 to 0.047 ) and (from 0.018 to $0.045 \mathrm{~g}$ ) for corn, wheat and rice grains during re-wetting process, respectively. Also, the water absorbed of grains was increased from $(0.0099$ to $0.0619 \mathrm{~g}),(0.0007$ to $0.0053 \mathrm{~g})$ and $(0.0005$ to $0.0050 \mathrm{~g})$ for corn, wheat and paddy rice grains during rewetting process, respectively. According to the previous results, it was noticed that by Increasing the moisture content, weight and water absorbed were increased for corn, wheat and rice grains during re-wetting process, respectively.

Fig. 4 shows the effect of moisture content on terminal velocity and hardness of grains during re-wetting process before starting the industrial of grains. It was noticed that the moisture content increased, which ranged from 12.5 to 20 $\%$ for corn, from 12 to $20 \%$ for wheat and from 11 to $20 \%$ for paddy rice grains during re-wetting process. The increasing of moisture content was lead to increase in terminal velocity of grains (from 60 to $82.5 \mathrm{~m} / \mathrm{s}$ ); (from 32 to $50 \mathrm{~m} / \mathrm{s}$ ) and (from 20 to $50 \mathrm{~m} / \mathrm{s}$ ) for corn, wheat and rice grains during re-wetting process, respectively. Meanwhile, the hardness of grains of grains was decreased from ( 259 to $155 \mathrm{~N}$ ), (56 to $21.45 \mathrm{~N}$ ) and (39 to $17 \mathrm{~N}$ ) for corn, wheat and rice grains during re-wetting process, respectively.According to the previous results, it was noticed that by increasing the moisture content, the weight was increased, while the hardness of grains was decreased for corn, wheat and paddy rice grains during re-wetting process, respectively.

Fig. 5 shows the relationship between the moisture content and electric resistance of grains during re-wetting process before starting the industrial of grains. For re-wetting process during three hours, it was noticed that the moisture content increased from 12.5 to $20 \%$ for corn, from 12 to $20 \%$ for wheat and from 11 to $20 \%$ for paddy rice grains crops respectively At increased soaking time from 0.5 to $3 \mathrm{~h}$ during re-wetting process, respectively. 

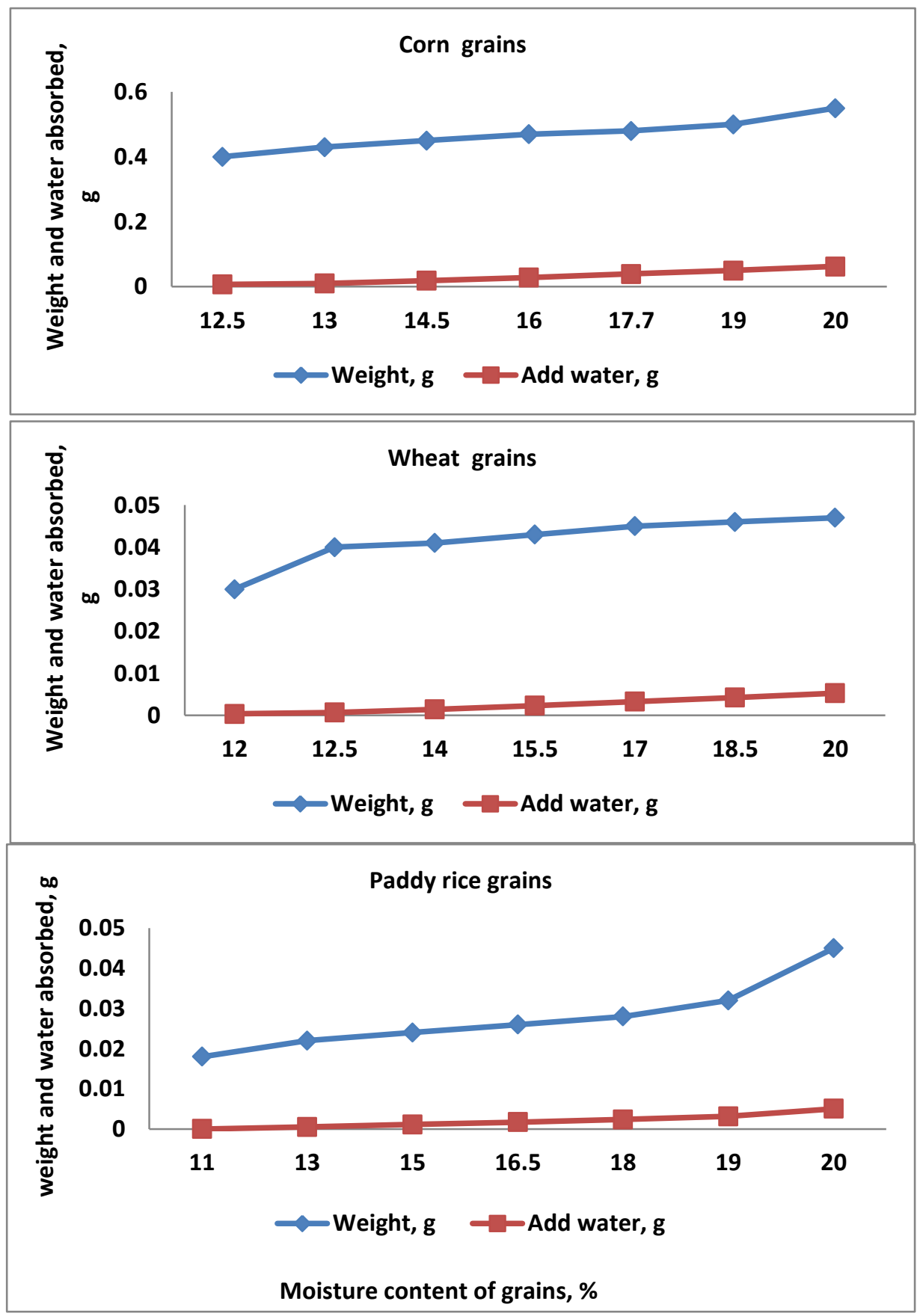

Fig. 3 : Relationship between weight and water absorbed of different grains. 


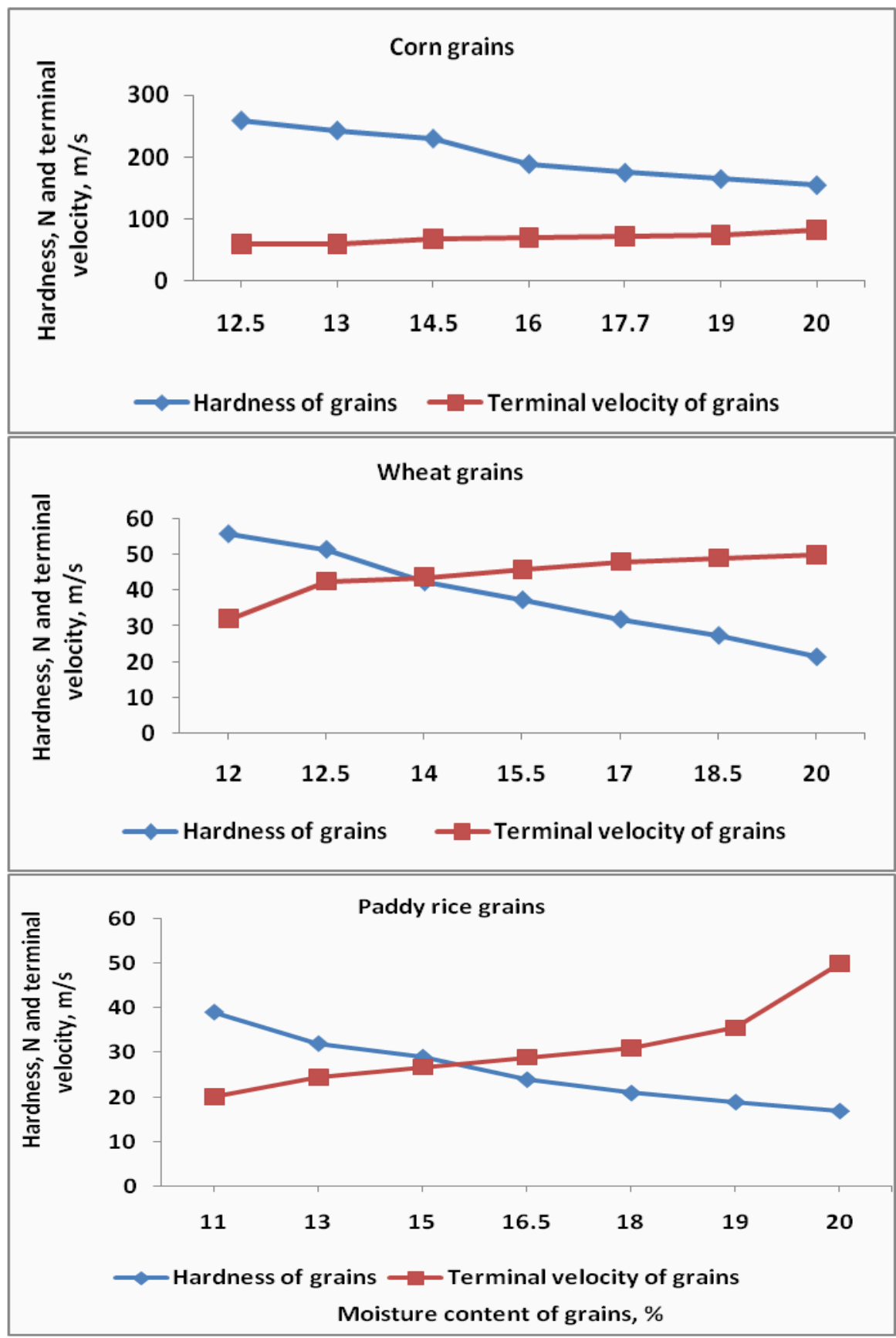

Fig. 4 : Relationship between moisture content, hardiness and terminal velocity of different grains 


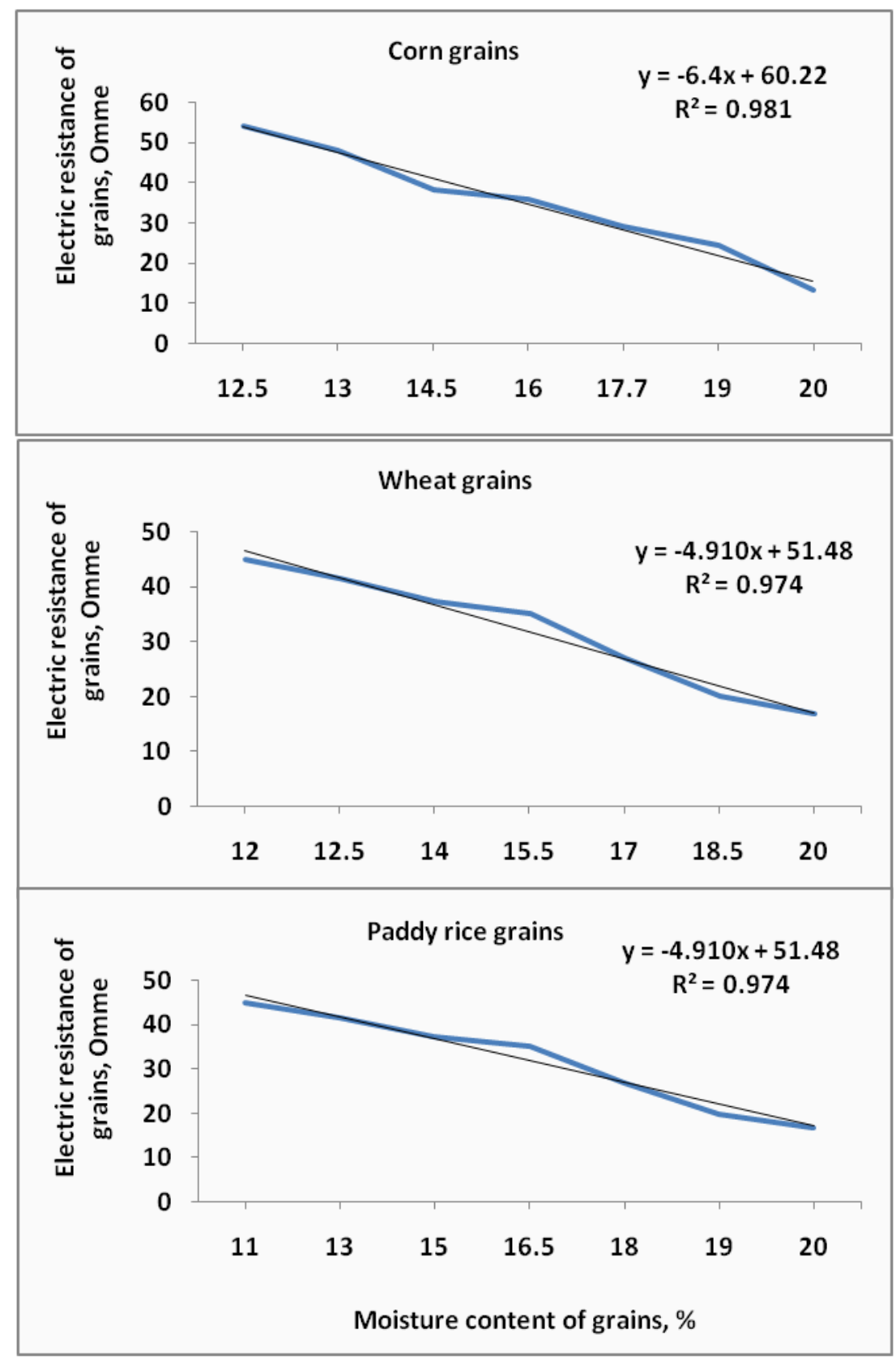

Fig. 5 : Relationship between moisture content and electric resistance of different grains

The increasing of moisture content was lead to decrease in electric resistance of grains from (54 to 13.2 Omme ),(45 to 16.9 Omme) and (44 
to 13 Omme) for corn, wheat and paddy rice grains crops, respectively. At increased soaking time from 0.5 to $3 \mathrm{~h}$ during re-wetting process respectively.

According to the previous results, there is relationship between the moisture content of grain and electric resistance for them, by increasing the moisture content, the electric resistance was decreased for corn, wheat and paddy rice of grains during re-wetting process.

The correlation factor between the moisture content and electric resistance was $0.98,0.97$ and 0.97 for corn, wheat and paddy rice grains during re-wetting process, respectively. That is mean the correlation factor was ranged between $r=0.97-0.98$ which is considered that the correlation relationship between the moisture content and electric resistance more significant and high. From the previous results it was showed the relationship between the moisture content and electric resistances as the following:

1- The relationship between the moisture content and electric resistance of corn grains is in the following equation:

$$
y=-6.4 x+60.221
$$

2- The relationship between the moisture content and electric resistance of wheat and paddy rice grains are in the following equation:

$$
y=-4.9107 x+51.486
$$

Table 2 shows the effect of re-wetting process on Consumption energy of grains. It was noticed that the grinding by a hammer mill showed the values of energy consumption were lead to reduce percentage about $20 \%$ of corn, wheat and rice grains resulted to re-wetting process of grains.

\begin{tabular}{|c|c|c|c|c|c|}
\hline \multirow{2}{*}{$\begin{array}{l}\text { Measuremen } \\
t \text { of graims }\end{array}$} & \multicolumn{2}{|c|}{ Before milling } & \multicolumn{2}{|c|}{ After milling } & \multirow{2}{*}{$\begin{array}{l}\text { Reduction } \\
\text { Energy, \% }\end{array}$} \\
\hline & $\begin{array}{c}\text { Moisture } \\
\text { Content, \% }\end{array}$ & $\begin{array}{l}\text { Consumption } \\
\text { energy, } \mathrm{kJ} / \mathrm{kg}\end{array}$ & $\begin{array}{c}\text { Moisture } \\
\text { Content, \% }\end{array}$ & $\begin{array}{l}\text { Consumption } \\
\text { Energy, kJ/kg }\end{array}$ & \\
\hline Corn & 13 & 175 & 17.8 & 139 & 20.6 \\
\hline Wheat & 12 & 155 & 17.5 & 124 & 20.0 \\
\hline Paddy Rice & 11 & 148 & 17.2 & 118 & 20.3 \\
\hline
\end{tabular}

Table (2):Consumption energy of grains before and after milling. 


\section{ONCLUSIONS}

The following conclusions were concluded:

1) The suitable moisture content was $16,15.5$ and $16.5 \%$ of corn, wheat and paddy rice grains, respectively. Which lead to increase weight of grains were $0.47,0.043$ and $0.026 \mathrm{~g}$ and water absorbed of grains was $0.0279,0.0023$ and $0.0017 \mathrm{~g}$. Meanwhile, the electric resistance of grains was decreased, which were $35.95,35.1$ and 32.2 Omme and terminal velocity was $70.5,45.9$ and $28.9 \mathrm{~m} / \mathrm{s}$, and hardness of grains was decreased from 189, 37.5 and $24 \mathrm{~N}$. of corn, wheat and paddy rice grains, respectively at about $1.5 \mathrm{hrs}$ of re-wetting time.

2) By increasing the moisture content, weight and water absorbed were increased. Meanwhile, the hardness and electric resistance of grain for corn, wheat and paddy rice grains during re-wetting process, respectively.

3) The correlation factor between the moisture content and electric resistance was $0.98,0.97$ and 0.97 for corn, wheat and paddy rice grains during re-wetting process, respectively. That is mean the correlation factor was ranged between $r=0.97-0.98$ which is considered that the correlation relationship between the moisture content and electric resistance more significant and high.,

4) It was found the negative relationship between the moisture content and electric resistance, 5) It was noticed that re-wetting process the grinding by a hammer mill showed the values of were lead to reduction percentage of consumption energy about $20 \%$ of grains., and 6) Re-wetting of grains can be important to most millers, preparation for the milling process and softens the endosperm to increase flour extraction and reduces the power consumption during the milling process.

\section{REFERENCES}

Abd EL-Kader, M.N. (1995).Effect of different sources of flour on some bakery products.Rural Home Economic Department. M.Sc. Thesis. Fac. Of Agric. Cairo Univ. PP. : 4-29.

Bizzarri, O., and Morelli, A. (1988).Milling of durum wheat. In G. Fabriani, \& C. Lintas (Eds.), Durum wheat: Chemistry and 
technology. American Association of Cereal Chemists: St. Paul, MN, USA. Pp.:161-189.

Cnossen, A. G and T. J. Siebenmorgen. (2000). The glass transition temperature concept in rice drying and tempering: effect on milling quality. Rice Quality Workshop 2003 Trans. ASAE 43(6):16611667.

Connel, P., Lawrance, L., and Nelson, R. (2004). Durum wheat: Australia's role in world markets. Australian Commodities, 11 (2): 319-324.

Dick, J. W., and Matsuo, R. R. (1988).Durum wheat and pasta products. In: Y. Pomeranz (Ed.), Wheat: chemistry and technology (3rd ed.). American Association of Cereal Chemists: St. Paul, MN, USA. Vol. II, pp. 507-547.

Doblado-Maldonado, A. F.; A. F. Rolando; and D. J. Rose (2013).Low moisture milling of wheat for quality testing of wholegrain flour.University of Nebraska, Lincoln, NE, USA.Journal of Cereal Science. Pp.: 1-4

Donnelly, B. J. and J. G. Ponte (2000). Pasta: Raw materials and processing. In K. Kulp\& J. G. Ponte (Eds.), Handbook of cereal science and technology (2nd ed.). Marcel Dekker, Inc. U. S. A. Pp.: 647-665.

El-Raie, A.E.S. (1987). Properties of shelled corn related to mechanical separation. Misr. J. Ag. Eng., 4 (1) : 36-52.

Hashemi, J.; A. Borghei; N. Shimizu and T. Kimura (2005).“'Optimization of final Moisture content of paddy in flat bed dryer with consideration of minimum losses and marketability in Iran" and Natural Reso.ofKhazar, 3(2), 72-82.

Hashemi, J.;1R. Tabatabaekoloor and T. Kimura (2009). Effects of discharge fan on the drying efficiency in flat-bed type dryer. Proc. world acad. sci, Eng. Tec.ISSN 2070-3740. 37:85-87

Hazen, S. P. and R.W.Ward (1997). Wheat milling and baking quality. Japan Crop Science 37 : 1079-1085. 
Laskowski J. and Lysiak G.(1997). Relationships between resistance characteristics of barely kernels and energy consumption during grinding no hammer mill. Int. Agrophysics, 11: 265-271.

Mark, F. (2003). Wheat tempering: mixer alternatives, department of grain science, MF3076, Publications from Kansas State University.Agricultural Experiment Station and Cooperative Extension Service. Pp.: 1-2

Matsuo, R. R. (1988). Evaluation of durum wheat, semolina, and pasta in Canada. In G. Fabriani\& C. Lintas (Eds.), Durum wheat: Chemistry and Technology American Association of Cereal Chemists, Inc. St. Paul, Minnesota, U.S.A. Pp.: 249-261.

Novales, B.; S. Guillaume; M. F. Devauxand M. Chaurand (1998). Particle size characterization of inflow milling products by video image analysis using Global features. Society of Chemical Industry J. Sc. Food Agric. 78 : 187-195.

Owens, G. (2003). “Mill Efficiency.” World Grain, July 2003, pages 2022.

Posner, E. S. and N. A. Hibbs (2005). "Wheat Flour Milling", 2d ed. American Association of Cereal Chemists, Inc.: St Paul Minnesota.

\section{Stoenescu, G.; V. Ionescu; I. Vasilean; I. Aprodu and I. Banu} (2010).Technological effects of the wheat cleaning equipment of an industrial mill.The Annals of the University Dunarea de Jos of Galati Fascicle VI - Food Technology, 34(2): 54 - 58.

Thiex, $\mathbf{N}$ and C. R. Richardson.(2003). Challenges in measuring moisture content of feeds. J. Anim. Sci. 81:3255-3266.

\section{Troccoli, A.; G. M. Borreli; P. De Vita; C.Fares and N. Di Fonzo} (2000). Durum wheat quality: A multidisciplinary concept. Journal of Cereal Science, 32: 99-113.

Woyniak, W. (2001).Mechanical properties of wheat grain in relation to internal cracks. Inst. Agrophysics, Polish Acad. Sciences, Poland. Int. Agrophysics, 15: 59-64 


\section{الملخص العربى}

التنبؤ بالمحتوى الرطوبى للحبوب خلال عملية الترطيب للطحن

\section{د.جمال كمال عرفة ' و ا.د./عبدالرحمن عبدالرؤف عبدالرحمن' '}

تهدف الدراسة الى دراسة المحتوى الرطوبى على بعض خصائص حبوب الذرة (صنف هجين

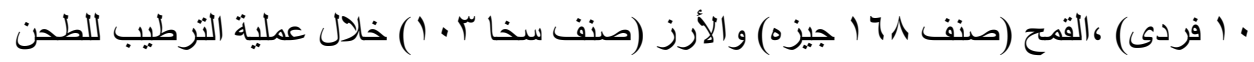

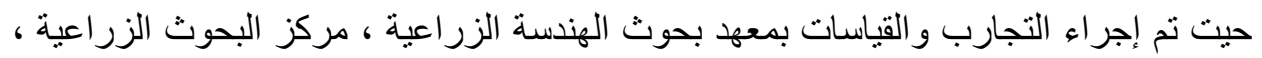

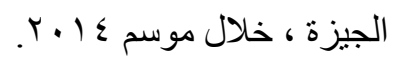
تم تجهيز العينات بتتظيفها من الأتربة وتكيفها ( عملية الترطيب لمدة ثلاث ساعات) و أجراء

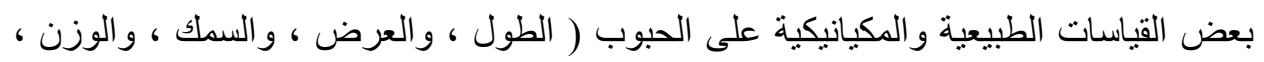
وسر عة التعليق، ودرجة الصلابه ) ثم عملية الطحن.

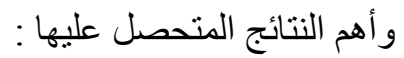

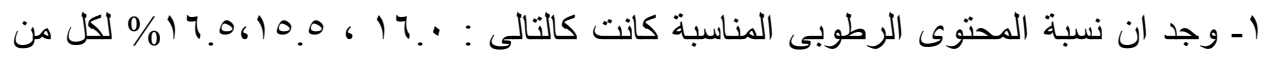

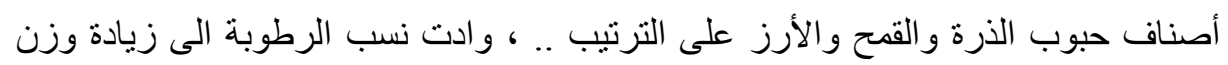

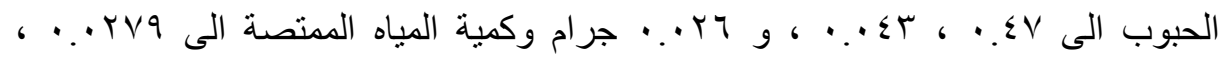

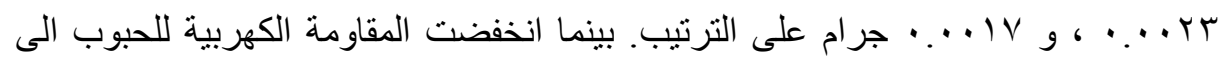

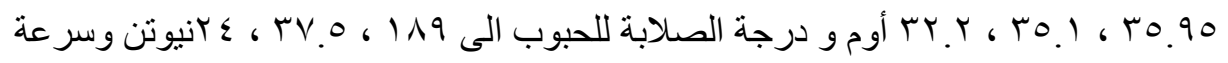

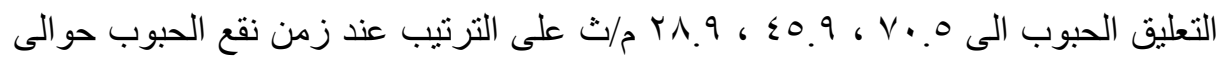

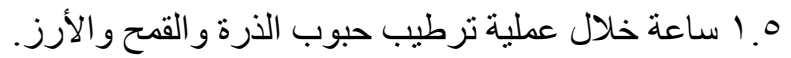

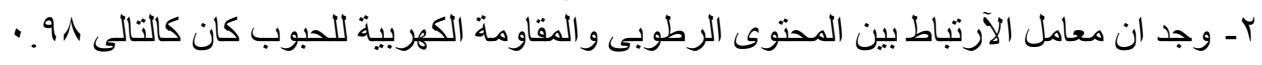

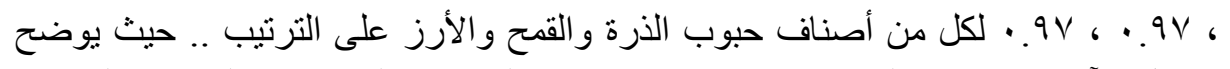
معامل الآرتباط بان هناك علاقة معنوية قوية بين المحتوى الرطوبى والمقاومة الرئ الكهرية الكربية

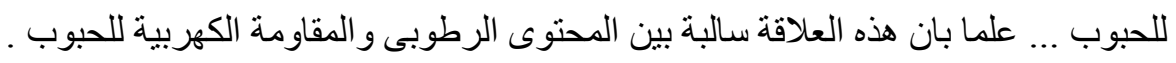

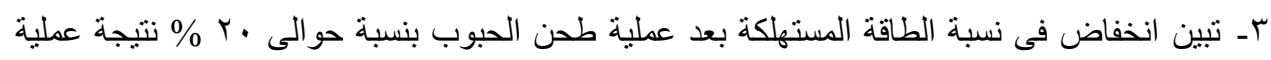

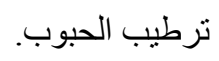
عـ تبين من الدراسة أهمية عملية ترطيب الحبوب خلال عمليات تداولها للتخزين ، أوالتصنيع وخصوصا عملية الطحن. 